\title{
Mathematics Learning Instructional Development based on Discovery Learning for Students with Intrapersonal and Interpersonal Intelligence (Preliminary Research Stage)
}

\author{
Yerizon ${ }^{1 *}$, Atus Amadi Putra ${ }^{1}$, Muhammad Subhan ${ }^{1}$ \\ ${ }^{1}$ Universitas Negeri Padang, INDONESIA \\ *CORRESPONDENCE: 《yerizon@yahoo.com
}

\begin{abstract}
The mathematical ability of Indonesian students is still very low compared to other countries. One alternative to overcome the problem is by creating learning instructional that allows students to learn well. Most of learning instructional developed today do not accommodate the student learning styles especially in schools that have classified students based on multiple intelligences. The dominant intelligences in the classroom are intrapersonal and interpersonal. The purpose of this research is to produce a mathematics learning instructional based on Discovery Learning approach that are valid, practical, and effective for junior high school students with intrapersonal and interpersonal intelligence. These instructional are developed using a development model adapted from the Plomp model. The development process of these instructional consists of 3 phases: front-end analysis/preliminary research, development/prototype phase and assessment phase. From the preliminary research results, we obtain that the intrapersonal student learning outcomes are not different from interpersonal. Teachers and students desperately need learning instructional with simple language and can guide students to understand the subject matter.
\end{abstract}

Keywords: learning instructional, multiple intelligences, development model

\section{INTRODUCTION}

The mathematical ability of Indonesian students is still low. Result of Trends in International Mathematics and Science Study (TIMSS) 2015 shows that the average score of eighth grade Indonesian students only 397 out of 500 and ranked 44th among 49 countries (Mullis, 2016). This result is a slightly increase compared to the 2011 TIMSS results, i.e. an average score of 386 (ranked 39th out of 43 countries). On the other hand, the result of the Program for International Student Assessment (PISA) 2015 shows that Indonesia ranked 63rd among 70 countries with the average score is 386 (OECD, 2016). This is a slight improvement from PISA 2012 result (ranked 64th of 65 countries and average score 375 ). The result also reveals that $68.6 \%$ of students' performance is below the second level and only $0.7 \%$ of them reach level five and six. It shows that the learning of mathematics in the class is not optimal yet. According to Organizational for Economic Co-operation and Development (OECD), students below the second level are considered not to be able to function effectively in the life of the 21 st century.

For many years, teachers or researchers tend to develop models or learning instructional without concerning the style of students learning specifically in schools that have classified students based on multiple intelligences. In the few past years, the research team has begun to develop a model of multiple intelligencebased learning at a junior high school SMPN 7 Padang that has multiple intelligences classes. From the results

Article History: Received 15 November $2017 \bullet$ Revised 22 February $2018 \bullet$ Accepted 22 February 2018

(C) 2018 The Author(s). Open Access terms of the Creative Commons Attribution 4.0 International License (http://creativecommons.org/licenses/by/4.0/) apply. The license permits unrestricted use, distribution, and reproduction in any medium, on the condition that users give exact credit to the original author(s) and the source, provide a link to the Creative Commons license, and indicate if they made any changes. 
of research and observations made, teachers still have difficulty in explaining the material to the students because it does not accommodate the different learning styles of students. For example, students with intrapersonal intelligence prefer to study on their own, while students with interpersonal intelligence prefer to study together.

The theory of multiple intelligences expresses the pluralistic view of the human mind which states that everyone has different cognitive potentials. There are at least eight intelligences of the same level: linguistic intelligence, logic-mathematical, musical, physical-kinesthetic, spatial, intrapersonal, interpersonal and naturalist. For that it takes various efforts to improve students' learning motivation based on the intelligence it has. Students with intrapersonal intelligence have the ability to recognize themselves (Perez, 2014). The main difference between interpersonal and intrapersonal intelligence is that intrapersonal intelligence regards one's feelings and emotions, while interpersonal intelligence allows the person to know the desires, feelings, and intentions of others (Pishghadam, 2009). It is important to create an atmosphere of learning that enables students to develop their abilities based on their own intelligence (Tamilselvi, 2015).

For that purpose, we want to design learning instructional that integrate student learning styles with multiple intelligences. Learning styles have a significant impact for students of mathematics, architecture and art (Behjat, 2012). Students will be more successful if they recognize the dominant type of intelligence within them. Although one type of intelligence can be dominant in an individual, it does not mean that another type does not exist within the individual. Any kind of intelligence can be developed (Pishghadam, 2009). Learning approach which accommodates different kind of student's intelligence makes possible for students to achieve more knowledge than conventional approach (Azid, 2016).

In this study, we design an instructional of learning mathematics using Discovery Learning approach for junior high school students with intrapersonal and interpersonal intelligence. Discovery learning is a learning process that emphasizes the intellectual mental of the students in solving various problems encountered, to find a concept or generalization that can be applied in the field (Illahi, 2012). Discovery learning is a learning process to find something new in teaching and learning activities. In discovery learning the learning process can find something if the teacher prepares in advance a variety of material to be delivered. Students are encouraged to primarily study themselves through active involvement by finding principles in understanding concepts (Whardani, 2015). Teachers encourage students to have experience and experiment by allowing them to discover principles for themselves.

In Discovery Learning, teachers do not deliver the materials or lessons directly to the students, but students are encouraged to identify what they want to know. As guidance, teachers can use scaffolding or giving certain tasks in form of students' worksheets.

To apply discovery learning methods in the classroom, there are several procedures that must be implemented in general teaching and learning activities as follows

\section{Stimulation}

At this stage, the students are confronted with problems related to the subject. The purpose is to create confusion so that arousing the students' desire to explore on their own. In this part, teachers can start learning activities by asking questions or ordering students to read some books.

\section{Problem Statement}

Following the stimulation, the next step is to give the teacher the opportunity to identify as many possible agenda issues as relevant to the lesson material. Then one of them is selected and formulated in the form of a hypothesis (temporary answer to the problem question). At this stage the teacher gives students opportunities to identify and analyze the problems they face. This technique is useful in building the mindset of the students to get them accustomed to finding a problem.

\section{Data Collection}

In this stage, students collect as much as possible relevant information about the given problems. This activity will give the students opportunity to find solutions or to prove their hypothesis. They can use varies way to collect relevant data such as reading literature, observing object, interviewing respondent, experimenting by themselves, and so forth. 


\section{Data Processing}

In this stage, all information obtained from the previous stage must be associated to get a valid conclusion. After comparing data with the related theory, students will analyze their connection in order to solve the problems. From this activity, students will gain new knowledge about alternative solutions of the problems.

\section{Verification}

Students in this stage will try to prove whether the hypothesis has been established or not with an alternative solution from data processing. The statements or hypotheses formulated earlier are checked, whether answered or not, whether proven or not.

\section{Generalization}

Based on result of verification process, students in this stage will draw a conclusion which is a general principle can be applied to all similar events or problems.

\section{RESEARCH METHOD}

This research is a development research using Plomp model which is aimed to develop valid and practical mathematics learning instructional with Discovery Learning approach for junior high school students with intrapersonal and interpersonal intelligence. The development process of this instructional consists of three phases: front-end analysis/preliminary research, development/prototyping phase and assessment phase. The front-end analysis stage consists of analysis of students and teacher needs, curriculum, and concepts learned in the school.

In phase development or prototyping phase (prototyping development stage), the instructional is developed step-by-step using formative evaluation. From this process, we produce Prototype 1, Prototype 2, and Prototype 3. Prototype 1 is the initial product and developed by doing self evaluation and expert reviews. After some revisions and get validity, Prototype 1 is developed into Prototype 2. Prototype 2 then must be tested its practicality by doing one-to-one evaluation. Evaluation per person is done by asking three students to comment on the device. Based on these evaluation results, revisions are made to the instructional device to produce Prototype 3 . Then, the field tests were conducted under conditions similar to the actual conditions. Field tests are carried out to see the level of device practicability that has been designed. Device practice is the user's disposal rate. Practices are viewed through observation during the execution of learning, interviews and questionnaires.

At the assessment stage, the effectiveness of the instructional is tested to see the effect of the product on the user. The effectiveness of this instructional can be seen from the students' test results of understanding the concept of mathematics after using it in their learning process.

\section{RESULT AND DISCUSSION}

From the questionnaire given to teacher and student, it is revealed the obstacles faced by teachers and students in the learning process. After that, teachers and students provide suggestions for improvement of further learning. Teachers and students were also asked about the implementation of learning using students' worksheet, namely LKPD.

A constraint faced by teachers in teaching mathematics is the difficulty in delivering learning materials. Because the ability of learners here varies widely, students with high abilities often feel bored because certain material is often repeated. We recommend that teachers provide additional material or provide challenging questions. They will be greatly helped to develop their competence. For almost all time, teachers focus on the completion of the course. For students with low ability, teachers have to repeat several times so that learners better understand.

In the learning process, teachers have not use the model of learning or teaching methods that vary in teaching mathematics. More methods using conventional methods (expository) just start with the giving of materials, sample questions, and exercises. This happens because students are not used to learning with new methods. Students are still familiar with the methods used by teachers so far. Other methods have been used by teachers of question and answer methods or discussion, but not good enough because smart students are active. 
To help students, teachers should provide teaching materials that enable students to learn more easily. One of the teaching materials that teachers can create is LKPD. Recently, teachers are not personally accustomed to make LKPD because they use LKPD prepared by the Mathematics Teacher Working Group (MGMP) or purchased at the bookstore. We recommend that teachers should joint MGMP activities in making LKPD of each taught material. If the teacher makes LKPD, then the teacher can adapt it to the characteristics and environment of the students.

According to the LKPD made by teachers from the MGMP, it is helpful to give a lot of practice questions and tasks at home, but most of the questions are emphasized for the arithmetic process. It is recommended that the problems presented can improve students' reasoning and problem-solving skills. For that LKPD created must make the students creative in solving the problem. During this time they are confused in completing the story. Teachers can ask guiding questions so that students can follow the procedures to be performed. Then LKPD should be written in a simpler, more interesting, and tangible example of easy, medium, to difficult. If LKPD is written like this then learners do not experience constraints understanding the material with learning approach to problem solving and positive impact for learners. Previous research (Ferrill, 2017) also mention that mathematical projects that supported by focused instruction are the key to guide students understanding of mathematics. The teacher considers that making LKPD is a new idea to support learning with problem-solving approach.

From the results of questionnaires given to the students obtained some important information about the learning process and teaching materials used so far. The questions are more focused on the LKPD characteristics that students want. In general, students feel that they need LKPD to understand the subject matter.

There are some difficulties experienced by students while studying with LKPD. The difficulties students encounter in understanding the subject matter of LKPD are less varied (59\%) and difficulty in understanding the problem (41\%).

\section{CONCLUSION}

Based on the research results, we can conclude that students need the student worksheet in learning mathematics. The worksheet should use varied examples and simple language. We recommend that teachers provide learning materials that are more easily understood and use a variety of methods. No potential conflict of interest was reported by the authors.

\section{Disclosure statement}

No potential conflict of interest was reported by the authors.

\section{Notes on contributors}

Yerizon - Doctor of Mathematics Education, Associate Professor, Mathematics Department, Universitas Negeri Padang, Padang, Indonesia.

Atus A. Putra - Master of Science, Lecturer, Mathematics Department, Universitas Negeri Padang, Padang, Indonesia.

Muhammad Subhan - Master of Science, Lecturer, Mathematics Department, Universitas Negeri Padang, Padang, Indonesia.

\section{REFERENCES}

Azid, N., \& Yaacob, A. (2016). Enriching Orphans' Potentials through Interpersonal and Intrapersonal Intelligence Enrichment Activities. International Journal of Instruction January 2016, 9(1). https://doi.org/10.12973/iji.2016.913a

Behjat, F. (2012) Interpersonal and intrapersonal intelligences: Do they really work in foreign-language learning? Procedia - Social and Behavioral Sciences No. 32, 351-355. https://doi.org/10.1016/j.sbspro.2012.01.052 
Ferrill, S. P. (2017) Discovery Learning Plus Direct Instruction Equals Success: Modifying American Math Education in the Algebra Classroom. Seattle Pacific University Honors Projects. Retrieved from http://digitalcommons.spu.edu/honorsprojects/63/

Illahi, M. T. (2012) Pembelajaran Discovery Strategy dan Mental Vocational Skill. Yogyakarta: DIVA Press.

Ishartono, N., Juniati, D., \& Lukito, A. (2016) Developing Mathematics Teaching Devices in the Topic of Trigonometry Basedon Guided Discovery Teaching Method. Journal of Research and Advances in Mathematics Education, 1(2), 154-171.

Mullis, I. V. S., Martin, M. O., Foy, P., \& Hooper, M. (2016). TIMSS 2015 International Results in Mathematics. Chestnut Hill, MA: TIMSS \& PIRLS International Study Center, Boston College. Retrieved from http://timssandpirls.bc.edu/timss2015/international-results/

OECD. (2016). PISA 2015 Result and Focus. Retrieved from www.oecd.org/ https://doi.org/10.1787/aa9237e6en

Perez, M. P., \& Ruz, N. R. (2014) Intrapersonal intelligence and motivation in foreign language learning. European Scientific, 10(17).

Pishghadam, R. (2009). Emotional and verbal intelligences in language learning. Iranian Journal of Language Studies 3, 43-64.

Tamilselvi, B., \& Geetha, D. (2015). Efficacy in teaching through "Multiple Intelligence" instructional strategies i-manager's. Journal on School Educational Technology, 11(2).

Whardani, S. et al (2015). Materi pelatihan guru implementasi kurikulum 2013. Yogyakarta: Kemendikbud. 